\title{
DUAL MODE ERROR ANALYSIS: PENYELESAIAN PERMASALAHAN LUAS PERMUKAAN SERTA VOLUME PRISMA DAN LIMAS SISWA KELAS VIII SMP
}

\author{
Endah Ayu $S^{1}$, Febrian ${ }^{2}$ \\ endahayu44@yahoo.com ${ }^{1}$, febrian@umrah.ac.id ${ }^{2}$ \\ Program Studi Pendidikan Matematika Fakultas Keguruan dan Ilmu Pendidikan \\ Universitas Maritim Raja Ali Haji \\ 2016
}

\begin{abstract}
Abstrak
Tujuan kajian ini adalah untuk mengetahui jenis-jenis kesalahan yang dilakukan siswa dalam menyelesaikan permasalahan luas permukaan serta volume pada prisma dan limas. Kajian ini dilakukan di kelas VIII SMP Muhammadiyah Tanjungpinang dengan jumlah siswa sebanyak 20 orang. Pengumpulan data dilakukan dengan wawancara singkat guru mata pelajaran serta metode tes sebanyak lima soal berbentuk uraian yang disusun melalui diskusi antara guru mata pelajaran dan penulis. Jawaban siswa dianalisis menggunakan dua perspektif (dual mode) kesalahan, menurut Watson dan Sukirman. Kesalahan siswa dalam perspektif Watson terdiri atas delapan kategorisasi yaitu: data tidak tepat, prosedur tidak tepat, data hilang, kesimpulan hilang, konflik level respon, manipulasi tidak langsung, masalah hierarki keterampilan, dan selain ketujuh kategori di atas. Sedangkan kesalahan siswa dalam perspektif Sukirman terdiri atas dua kategorisasi yaitu: kesalahan yang bersifat sistematis dan konsisten, serta kesalahan yang bersifat insidental. Hasil analisis menunjukkan persentase dari setiap kesalahan pada kategori kesalahan Watson yaitu data tidak tepat sebesar 18,54\%, prosedur tidak tepat sebesar $36,42 \%$, data hilang sebesar 10,60\%, kesimpulan hilang sebesar 5,30\%, konflik level respon sebesar 5,30\%, manipulasi tidak langsung sebesar 13,24\%, masalah hirarki keterampilan sebesar 10,60\% dan kesalahan selain ketujuh kategori di atas sebesar $0 \%$. Sedangkan persentase dari kesalahan berdasarkan kategorisasi kesalahan Sukirman adalah kesalahan sistematis dan konsisten sebesar $41,72 \%$ serta kesalahan insidental sebesar $58,28 \%$.
\end{abstract}

Kata Kunci : dual mode error analysis, kategori kesalahan Watson dan Sukirman

\footnotetext{
Abstract

This study aims at recognizing the types of error emerged by the students while solving problems on the topic of area and volume of prism and pyramid. This study was conducted at class VIII SMP Muhammadiyah Tanjungpinang including 20 students. Data collection was undertaken by conducting interview with mathematics teacher and posing a test containing five essay problems constructed based on discussion among teacher and researcher. Students' answers were analyzed by using dual mode error analysis: Watson and Sukirman. Error types based on Watson are: inappropriate data, inappropriate
} 
procedure, omitted data, omitted conclusion, response level conflict, undirected manipulation, skills hierarchy problem, error other than previous seven. Error type based on Sukirman are: systematic and consistent error, and incidental error. The result showcased the percentages of emerging error based on Watson are: inappropriate data $18.54 \%$, inappropriate procedure $36.42 \%$, omitted data $10.60 \%$, omitted conclusion $5.30 \%$, response level conflict $5.30 \%$, undirected manipulation $13.24 \%$, skills hierarchy problem $10.60 \%$, and others $0 \%$. On the other hand, the percentages of error based on Sukirman are: systematic and consistent error $41.72 \%$, and incidental error 58.28\%.

Keywords: dual mode error analysis, Watson error category, Sukirman error category

\section{Pendahuluan}

\section{Latar Belakang}

Belajar dapat diartikan sebagai tahapan perubahan seluruh tingkah laku yang relatif menetap sebagai hasil dari pengalaman atau tingkah laku dan interaksi dengan lingkungan yang melibatkan proses kognitif (Muhibbin Syah:2006). Sedangkan matematika adalah disiplin ilmu yang mempelajari tentang tata cara berpikir dan mengolah logika, baik secara kualitatif maupun secara kuantitatif (Erman Suherman, 2003:298).

Dalam hal ini, belajar matematika dapat dikatakan perubahan yang melibatkan proses berpikir pada siswa yang terjadi akibat adanya sentuhan terhadap pengalaman dan tingkah laku dengan lingkungannya dimana perubahan tersebut bersifat positif sehingga membentuk pola pikir yang masuk akal serta dapat dibuktikan dengan jelas. Melalui pembelajaran matematika, siswa diharapkan mampu menggunakan kemampuan berpikir secara logis, kritis, cermat dan kreatif sehingga mampu membawa perubahan positif terutama terhadap diri siswa terlebih dahulu.

Menurut Winkel dan Mukhtar (Sudaryono, 2012:44), pemahaman adalah kemampuan seseorang untuk menangkap makna dan arti dari bahan yang dipelajari, yang dinyatakan dengan menguraikan isi kemudian dapat diketahui hal-hal yang menjadi kelemahan siswa untuk kemudian dapat dilakukan langkahlangkah guna mengurangi kesalahan siswa tersebut dan menambah pemahaman siswa atas materi yang disampaikan.

Dalam kajian ini, hal yang menjadi pokok bahasan yaitu luas permukaan serta volume pada prisma dan limas yang merupakan salah satu materi lanjutan dari bangun datar. Analisis kesalahan siswa ketika menyelesaikan permasalahan luas dan volume prisma dan limas menjadi aspek penting pada kajian ini.

Untuk mengetahui kategori kesalahan siswa, dalam permasalahan luas permukaan serta volume pada prisma dan limas akan digunakan ketegori kesalahan menurut Watson dan Sukirman (dual mode analysis error). Kedua perspektif ini memiliki kategorisasi yang saling mendukung serta dapat digunakan untuk mengetahui kesalahan apa saja yang dialami siswa secara lebih terperinci. Hanya saja pada kesalahan Sukirman terdapat dua kategorisasi kesalahan yang memiliki sudut pandang yang bersifat lebih umum jika dibandingkan dengan kesalahan menurut Watson yang sifatnya lebih terperinci atau mendetail. Kedua perspektif ini, digunakan dalam kajian guna menjangkau setiap kesalahan yang mungkin dilakukan oleh siswa dalam menyelesaikan soal yang berkaitan dengan prisma dan limas.

\section{Tujuan}

Adapun tujuan dari dilakukannya kajian ini yaitu untuk mengetahui sejauh mana pemahaman siswa terhadap materi yang disampaikan serta mengetahui tipe kesalahan yang dilakukan oleh siswa dalam menyelesaikan persoalan luas permukaan dan volume prisma dan limas.

\section{Pertanyaan Studi}

Berdasarkan uraian pada latar belakang diatas, maka dapat dirumuskan permasalahan sebagai berikut: 
a. Apa saja kesalahan siswa dalam menyelesaikan permasalahan luas permukaan serta volume pada prisma dan limas berdasarkan kategori kesalahan Watson dan Sikirman?

b. Berapa persentase kesalahan siswa dalam menyelesaikan permasalahan luas permukaan serta volume pada prisma dan limas berdasarkan kategori kesalahan menurut Watson dan Sukirman?

\section{Metode Penelitian Jenis Penelitian}

Analisis kesalahan pada studi ini berjenis analisis deskriptif yang bersifat mendeskripsikan suatu keadaan maupun kondisi secara ilmiah (Masyhud, 2012). Dengan demikian, jenis penelitian ini adalah analisis deskriptif.

\section{Subjek}

Subjek dalam kajian ini adalah siswa SMP Muhammadiyah Tanjungpinang kelas VIII pada semester genap tahun ajaran 2015/2016 dengan jumlah siswa sebanyak 20 yang terdiri dari 14 siswa laki-laki dan 6 siswa perempuan.

Berdasarkan wawancara singkat dengan guru mata pelajaran, diketahui bahwa secara umum kemampuan siswa terhadap matematika relatif rendah hal ini dibuktikan dengan sulitnya siswa dalam memahami setiap penjelasan yang disampaikan oleh guru. Topik yang sedang dipelajari oleh siswa saat dilakukan kajian yaitu luas permukaan serta volume pada prisma dan limas dimana siswa sedang dalam masa pembahasan soal untuk persiapan ujian semester genap.

\section{Instrumen/ Perangkat}

Untuk mengetahui kemungkinan kesalahan yang muncul di kalangan siswa, pengkaji memberikan lima butir soal yang harus diselesaikan oleh siswa dengan waktu yang telah ditetapkan. Soal disediakan dalam bentuk essay tes, dimana siswa dituntut untuk menjawab soalan dalam bentuk menguraikan, menjelaskan, memberikan alasan dan bentuk lain yang sesuai dengan tuntutan soal. Tipe soal ini dipilih sebab dengan menggunakan tipe soal ini, mempermudah prose pendeteksian kesalahan yang dilakukan oleh siswa. Sebelum memberikan soal tersebut kepada siswa, dilakukan konsultasi dan diskusi bersama guru mata pelajaran yang bersangkutan agar setiap soal yang diberikan sesuai dengan kemampuan dan pemahaman siswa sehingga soal tersebut layak untuk diuji cobakan.

Dalam penyusunan soal, penulis menggunakan soal pada tingkat pemahaman atau comprehension (C2) berdasarkan Benjamin S. Bloom dalam Nirsam (2005:21) dimana dalam menjawab setiap soalan hanya memerlukan pemahaman atas materi yang disampaikan tanpa memerlukan analisis lebih lanjut. Pada jenjang ini siswa dituntut untuk mengerti dan memahami konsep yang dipelajari.

\section{Pengumpulan Data}

Dalam teknik pengumpulan data, setelah melakukan konsultasi dan diskusi dengan guru mata pelajaran, penulis memberikan soalan tersebut untuk dapat dikerjakan oleh siswa. Siswa diberikan waktu 90 menit untuk menyelesaikan soal yang diberikan. Hasil dari jawaban siswa tersebutlah yang menjadi data tertulis bagi penulis yang kemudian dianalisis untuk diketahui kelemahan-kelemahan siswa dalam menyelesaikan soal mengenai luas permukaan serta volume prisma dan limas.

\section{Proses Analisa}

Dalam kajian ini terdapat beberapa tahapan yang dilalui yaitu pendahuluan, pembuatan soal tes, validasi soal tes, pelaksanaan tes, wawancara guru mata pelajaran, analisa hasil tes, dan penarikan kesimpulan.

Kajian ini menggunakan dua metode pengumpulan data yaitu wawancara dan pemberian essay tes. Dimana wawancara dilakukan dengan guru matematika untuk melengkapi beberapa data yang dianggap perlu. Namun dalam pelaksanaannya, wawancara tersebut tidak dilakukan secara mendetail mengingat topik utama dalam kajian ini yaitu memberi serta menganalisis hasil tes siswa.

Untuk mengetahui jenis-jenis kesalahan yang dilakukan oleh siswa dalam menyelesaikan soal tes yang diberikan, penulis menggunakan 
dua perspektif ahli kategorisasi kesalahan siswa dalam menjawab soal tes tersebut. Dimana setiap jawaban siswa per butir soal dianalisis secara mendalam menggunakan kategori kesalahan menurut Watson dan Sukirman.

Sukirman menyatakan bahwa kesalahan merupakan penyimpangan terhadap hal-hal yang benar yang sifatnya sistematis, konsisten, maupun insidental pada daerah tertentu. Kesalahan yang sistematis dan konsisten terjadi disebabkan oleh tingkat penguasaan materi yang kurang pada siswa. Sedangkan kesalahan yang bersifat insidental adalah kesalahan yang bukan merupakan akibat dari rendahnya tingkat penguasaan materi pelajaran, melainkan oleh sebab lainnya seperti kurang cermat dalam membaca untuk memahami maksud soal, kurang cermat dalam menghitung atau bekerja secara tergesa-gesa karena merasa diburu waktu yang tinggal sedikit (Sukirman,1985:16).

Sedangkan kategorisasi kesalahan menurut Watson yaitu: data tidak tepat (inappropriate data/id), prosedur tidak tepat(inappropriate procedure/ip), data hilang(ommited data/od), kesimpulan hilang (ommited conclusion/oc), konflik level respon (response level conflict/rlc), manipulasi tidak langsung (undirected manipulation/um), masalah hirarki keterampilan (skills hierarchy problem/shp), selain ketujuh kategori diatas (above other/ao).

Kedua teori kesalahan di atas memiliki relasi satu sama lain dimana pada teori Sukirman lebih merujuk kepada kesalahan siswa yang sifatnya lebih umum dibandingkan kesalahaan menurut Watson. Sehingga dalam kajian ini penulis menggunakan kedua teori diatas untuk menunjang kajian sehingga kesalahan yang dilakukan siswa dapat di diagnosis serta di analisis secara mendetail. Penulis juga mengkategorisasikan beberapa kesalahan Watson kedalam kategorisasi kesalahan menurut Sukirman yaitu sebagai berikut.

1. Kesalahan yang sistematis dan konsisten menurut Sukirman, secara lebih spesifik dapat di spesifikasikan atas beberapa kesalahan menurut Watson yang terdiri atas kesalahan prosedur tidak tepat (inappropriate procedure/ip), serta konflik level respon (response level conflict/rlc).

2. Kesalahan yang bersifat insidental menurut Sukirman, secara lebih spesifik dapat dispesifikasikan atas beberapa kesalahan menurut Watson yang terdiri atas kesalahan data tidak tepat (inappropriate data/id), data hilang( ommited data/od), kesimpulan hilang (ommited conclusion/oc), manipulasi tidak langsung (undirected manipulation/um), serta masalah hirarki keterampilan (skills hierarchy problem/shp).

\section{Hasil dan Pembahasan \\ Hasil Kajian}

Perhitungan presentase kesalahan siswa menggunakan pendekatan

$$
\mathrm{P}=\frac{N}{n} x 100 \%
$$

$\mathrm{N}$ : banyaknya kesalahan siswa per kategorisasi tiap soal

$\mathrm{N}$ : banyaknya kesalahan siswa tiap soal

Hasil analisa data menunjukkan persentase kesalahan yang dilakukan siswa pada soal nomor 1a untuk kesalahan prosedur tidak tepat (inappropriate procedure/ip) menurut Watson yaitu sebesar 90,91\% dan 9,09\% pada kesalahan data hilang (inappropriate data/id). Sedangkan persentase siswa yang melakukan kesalahan sistematis dan konsisten menurut Sukirman untuk soal nomor 1a sebesar 90,91\% dan 9,09\% melakukan kesalahan insidental dengan banyak siswa yang menjawab benar yaitu sebanyak 9 siswa.

Persentase kesalahan yang dilakukan siswa pada soal nomor $1 \mathrm{~b}$ untuk kesalahan data tidak tepat (inappropriate data/id) menurut Watson sebesar 13,33\%, kesalahan prosedur tidak tepat (inappropriate procedure/ip) sebesar $60 \%$, dan 26,66\% untuk kesalahan data hilang (ommited data/od). Sedangkan presentase siswa yang yang melakukan kesalahan sistematis dan konsisten menurut Sukirman yaitu sebesar $60 \%$ dan $40 \%$ melakukan kesalahan insidental 
dengan 1 siswa tidak menjawab dan 10 siswa menjawab benar.

Persentase kesalahan yang dilakukan siswa pada soal nomor 1c untuk kesalahan prosedur tidak tepat (inappropriate procedure/ip) sebesar $91,66 \%$ dan $8,34 \%$ melakukan kesalahan data hilang (ommited data/od) dalam kategori kesalahan menurut Watson. Sedangkan presentase siswa yang melakukan kesalahan sistematis dan konsisten menurut Sukirman sebesar 91,66\% dan 8,34\% melakukan kesalahan insidental dengan banyak siswa yang menjawab benar yaitu 8 siswa.

Persentase kesalahan yang dilakukan siswa pada soal nomor 2 untuk kesalahan data tidak tepat (inappropriate data/id) menurut Watson sebesar 25,64\%, kesalahan prosedur tidak tepat (inappropriate procedure/ip) sebesar $15,38 \%$, kesalahan data hilang (ommited data/od) sebesar 5,13\%, kesalahan kesimpulan hilang (ommited conclusion/oc) sebesar 10,25\%, dan kesalahan manipulasi tidak langsung (undirected manipulation/um) sebesar 28,20\% serta kesalahan masalah hirarki keterampilan (skill hierarchy problem /shp) yaitu sebesar $15,40 \%$.

Sedangkan persentase kesalahan menurut Sukirman untuk soal nomor 2 pada kesalahan sistematis dan konsisten sebesar $15,38 \%$ dan persentase yang melakukan kesalahan insidental sebesar 84,62\%. Dengan banyak siswa yang menjawab benar yaitu 4 siswa.

Persentase kesalahan yang dilakukan siswa pada soal nomor 3 untuk kesalahan data tidak tepat (inappropriate data/id) sebesar $5,71 \%$, kesalahan prosedur tidak tepat (inappropriate procedure/ip) sebesar 17,14\%, kesalahan data hilang (ommited data/od) sebesar $20 \%$, kesalahan kesimpulan hilang (ommited conclusion/oc) sebesar 5,71\%, kesalahan konflik level respon (response level conflict/rlc) sebesar $5,71 \%$, kesalahan manipulasi tidak langsung (undirected manipulation/um) sebesar 25,71\%, dan kesalahan masalah hirarki keterampilan (skill hierarchy problem/shp) yaitu sebesar $20 \%$.
Sedangkan persentase kesalahan menurut Sukirman untuk soal nomor 3 pada kesalahan sistematis dan konsisten yaitu sebesar $22,86 \%$ dan persentase kesalahan insidental sebesar $77,14 \%$. Dengan banyak siswa yang menjawab benar yaitu 2 siswa dan banyak siswa yang tidak menjawab yaitu 4 siswa.

Persentase kesalahan yang dilakukan siswa pada soal nomor 4 untuk kesalahan data tidak tepat (inappropriate data/id) sebesar $42,10 \%$, kesalahan prosedur tidak tepat (inappropriate procedure/ip) sebesar 36,84\%, kesalahan data hilang (ommited data/od) sebesar $5,26 \%$, kesalahan kesimpulan hilang (ommited conclusion/oc) sebesar 10,52\%, dan kesalahan masalah hirarki keterampilan (skill hierarchy problem/shp) yaitu sebesar 5,26\%.

Sedangkan persentase kesalahan menurut Sukirman pada soal nomor 4 untuk kesalahan sistematis dan konsistensi yaitu sebesar 36,84\% dan kesalahan insidental yaitu sebesar $63,16 \%$. Dengan banyak siswa yang tidak menjawab yaitu 11 siswa.

Persentase kesalahan yang dilakukan siswa pada soal nomor 5 untuk kesalahan data tidak tepat (inappropriate data/id) sebesar 30\%, kesalahan prosedur tidak tepat (inappropriate procedure/ip) sebesar 30\%, kesalahan konflik level respon (response level conflict/rlc) sebesar $30 \%$ dan kesalahan masalah hirarki keterampilan (skill hierarchy problem/shp) sebesar $10 \%$. Sedangkan persentase kesalahan menurut Sukirman untuk soal nomor 5 pada kesalahan sistematis dan konsisten sebesar $60 \%$ dan kesalahan insidental sebesar 40\%. Dengan banyak siswa yang tidak menjawab yaitu sebanyak 13 siswa.

Sedangkan berdasarkan perhitungan presentase kesalahan siswa menggunakan pendekatan,

$$
\mathrm{P}=\frac{J}{j} \times 100 \%
$$

J : Jumlah satu kategori kesalahan

$\mathrm{J}$ : Jumlah seluruh kesalahan siswa

Hasil analisa kesalahan yang diperoleh yaitu persentase kesalahan yang dilakukan siswa menurut Watson pada kesalahan data tidak tepat (inappropriate data/id) sebesar 18,54\%, 
JURNAL GANTANG Pendidikan Matematika FKIP - UMRAH

Vol. 1 No. 2, Desember 2016, p-ISSN. 2503-0671, e-ISSN. 2548-5547

kesalahan prosedur tidak tepat (inappropriate procedure/ip) sebesar $36,42 \%$, kesalahan data hilang (ommited data/od) sebesar 10,54\%, kesalahan kesimpulan hilang (ommited conclusion/oc) sebesar 5,29\%, kesalahan konflik level respon (response level conflict/rlc) sebesar $5,29 \%$, kesalahan manipulasi tidak langsung (undirected manipulation/um) sebesar 13,24 dan kesalahan masalah hirarki keterampilan (skill hierarchy problem/shp) sebesar 10,59\% serta kesalahan selain ketujuh kategori diatas (above other/ao) yaitu sebesar $0 \%$.

Berikut adalah tabel analisis kesalahan yang dilakukan oleh siswa guna menjadi salah satu pedoman penulis dalam melakukan analisis untuk mengetahui kelemahan serta kendala siswa dalam menyelesaikan permasalahan luas permukaan serta volume prisma dan limas. 
Tabel Analisis Kesalahan Dalam Menjawab Soalan Essay Oleh Siswa Kelas XI

SMP Muhammadiyah Tanjungpinang

\begin{tabular}{|c|c|c|c|c|c|c|c|c|c|c|c|c|c|c|c|c|c|c|c|c|c|c|c|c|c|c|c|}
\hline & \multicolumn{9}{|c|}{ Analisis Kesalahan Siswa u/ Soal Nomor 1a } & \multicolumn{9}{|c|}{ Analisis Kesalahan Siswa u/ Soal Nomor 1b } & \multicolumn{9}{|c|}{ Analisis Kesalahan Siswa u/ Soal Nomor 1c } \\
\hline Nama & W1 & $\mathrm{W} 2$ & W3 & W4 & W5 & W6 & W7 & W8 & Ket & W1 & W2 & W3 & W4 & W5 & W6 & W7 & W8 & Ket & W1 & W2 & W3 & W4 & W5 & W6 & W7 & W8 & Ket \\
\hline Abdu & & & & & & & & & $\mathrm{B}$ & & $\sqrt{ }$ & & & & & & & S1 & & $\sqrt{ }$ & & & & & & & S1 \\
\hline Alif & & & & & & & & & B & & & & & & & & & B & & & & & & & & & B \\
\hline Anggi & & $\sqrt{ }$ & & & & & & & $\mathrm{S} 1$ & & & & & & & & & B & & & & & & & & & B \\
\hline Anjar & & & & & & & & & $\mathrm{B}$ & & & & & & & & & T.A.J & & $\sqrt{ }$ & & & & & & & S1 \\
\hline Apri & & & & & & & & & B & & & & & & & & & B & & $\sqrt{ }$ & & & & & & & S1 \\
\hline Chand & & & & & & & & & B & & $\sqrt{ }$ & & & & & & & S1 & & & & & & & & & B \\
\hline Fauz & & $\sqrt{ }$ & & & & & & & S1 & & & & & & & & & $\mathrm{B}$ & & . & $\sqrt{ }$ & & & & & & S2 \\
\hline Indah & & $\sqrt{ }$ & & & & & & & S1 & & $\sqrt{ }$ & $\sqrt{ }$ & & & & & & S1S2 & & $\sqrt{ }$ & & & & & & & S1 \\
\hline Jaya & & & $\sqrt{ }$ & & & & & & $\mathrm{S} 2$ & & & & & & & & & B & & $\sqrt{ }$ & & & & & & & S1 \\
\hline Alvon & & $\sqrt{ }$ & & & & & & & $\mathrm{S} 1$ & $\sqrt{ }$ & $\sqrt{ }$ & & & & & & & $\overline{S 1 S 2}$ & & $\sqrt{ }$ & & & & & & & S1 \\
\hline Hafiz & & $\sqrt{ }$ & & & & & & & S1 & & & & & & & & & B & & & & & & & & & B \\
\hline Misla & & $\sqrt{ }$ & & & & & & & S1 & & & & & & & & & B & & $\sqrt{ }$ & & & & & & & S1 \\
\hline$\overline{\text { Radi }}$ & & $\sqrt{ }$ & & & & & & & $\mathrm{S} 1$ & & $\sqrt{ }$ & & & & & & & $\bar{S} 1$ & & $\sqrt{ }$ & & & & & & & $\overline{S 1}$ \\
\hline Ridho & & & & & & & & & B & $\sqrt{ }$ & $\sqrt{ }$ & & & & & & & S1S2 & & & & & & & & & B \\
\hline Rio & & $\sqrt{ }$ & & & & & & & S1 & & & & & & & & & $\bar{B}$ & & & & & & & & & $\bar{B}$ \\
\hline Risa & & & & & & & & & $\mathrm{B}$ & & & & & & & & & $\mathrm{B}$ & & & & & & & & & $\mathrm{B}$ \\
\hline Sefri & & & & & & & & & B & & & & & & & & & B & & $\sqrt{ }$ & & & & & & & S1 \\
\hline Syah & & $\sqrt{ }$ & & & & & & & $\mathrm{S} 1$ & & $\sqrt{ }$ & $\sqrt{ }$ & & & & & & S1S2 & & $\sqrt{ }$ & & & & & & & S1 \\
\hline Tobi & & & & & & & & & $\mathrm{B}$ & & $\sqrt{ }$ & $\sqrt{ }$ & & & & & & S1S2 & & & & & & & & & $\mathrm{B}$ \\
\hline Wind & & $\sqrt{ }$ & & & & & & & S1 & & $\sqrt{ }$ & $\sqrt{ }$ & & & & & & S1S2 & & $\sqrt{ }$ & & & & & & & S1 \\
\hline
\end{tabular}


JURNAL GANTANG Pendidikan Matematika FKIP - UMRAH

Vol. 1 No. 2, 2016, p-ISSN. 2503-0671, e-ISSN. 2548-5547

\begin{tabular}{|c|c|c|c|c|c|c|c|c|c|c|c|c|c|c|c|c|c|c|c|c|c|c|c|c|c|c|c|}
\hline & \multicolumn{9}{|c|}{ Analisis Kesalahan Siswa u/ Soal Nomor 2} & \multicolumn{9}{|c|}{ Analisis Kesalahan Siswa u/ Soal Nomor 3} & \multicolumn{9}{|c|}{ Analisis Kesalahan Siswa u/ Soal Nomor 4} \\
\hline Nama & W1 & W2 & W3 & W4 & W5 & W6 & W7 & W8 & Ket & W1 & W2 & W3 & W4 & W5 & W6 & W7 & W8 & Ket & W1 & W2 & W3 & W4 & W5 & W6 & W7 & W8 & Ket \\
\hline Abdu & & & & & & & $\sqrt{ }$ & & S2 & & & $\sqrt{ }$ & & & & & & S2 & & & & & & & & & T.A.J \\
\hline Alif & & & & & & & & & B & & $\sqrt{ }$ & $\sqrt{ }$ & $\sqrt{ }$ & $\sqrt{ }$ & & & & S1S2 & & & & & & & & & T.A.J \\
\hline Anggi & $\sqrt{ }$ & & & $\sqrt{ }$ & & $\sqrt{ }$ & & & S2 & & & & & & $\sqrt{ }$ & $\sqrt{ }$ & & S2 & & & & & & & & & T.A.J \\
\hline Anjar & & & & & & & & & $\mathrm{B}$ & $\sqrt{ }$ & $\sqrt{ }$ & & & & $\sqrt{ }$ & $\sqrt{ }$ & & S1S2 & & & & & & & & & T.A.J \\
\hline Apri & & & & & & $\sqrt{ }$ & $\sqrt{ }$ & & S2 & & & & & & $\sqrt{ }$ & $\sqrt{ }$ & & S2 & $\sqrt{ }$ & $\sqrt{ }$ & & & & & & & S1S2 \\
\hline Chan & & & & $\sqrt{ }$ & & $\sqrt{ }$ & & & S2 & & & & & & & & & T.A.J & & & & & & & & & T.A.J \\
\hline Fauz & $\sqrt{ }$ & & $\sqrt{ }$ & $\sqrt{ }$ & & $\sqrt{ }$ & & & S1S2 & & & & & & & & & T.A.J & & & & & & & & & T.A.J \\
\hline Indah & $\sqrt{ }$ & $\sqrt{ }$ & & & & & & & S1S2 & & & $\sqrt{ }$ & & & $\sqrt{ }$ & $\sqrt{ }$ & & S1S2 & $\sqrt{ }$ & & & & & & $\sqrt{ }$ & & S2 \\
\hline Jaya & & & & & & & & & B & & & $\sqrt{ }$ & & & $\sqrt{ }$ & $\sqrt{ }$ & & S1S2 & & & & & & & & & T.A.J \\
\hline Alvon & $\sqrt{ }$ & & $\sqrt{ }$ & & & $\sqrt{ }$ & & & S1S2 & & & $\sqrt{ }$ & & & $\sqrt{ }$ & $\sqrt{ }$ & & S1S2 & $\sqrt{ }$ & $\sqrt{ }$ & & & & & & & S1S2 \\
\hline Hafiz & & & & & & $\sqrt{ }$ & $\sqrt{ }$ & & S2 & & $\sqrt{ }$ & $\sqrt{ }$ & & & $\sqrt{ }$ & & & S1S2 & $\sqrt{ }$ & $\sqrt{ }$ & $\sqrt{ }$ & & & & & & S1S2 \\
\hline Misla & & & & & & $\sqrt{ }$ & & & S2 & & $\sqrt{ }$ & & & & . & & & S1 & $\sqrt{ }$ & $\sqrt{ }$ & & & & & & & S1S2 \\
\hline Radika & & $\sqrt{ }$ & & & & $\sqrt{ }$ & $\sqrt{ }$ & & S1S2 & & & & & & & & & T.A.J & & & & & & & & & T.A.J \\
\hline Ridho & & & & & & & & & $\mathrm{B}$ & $\sqrt{ }$ & $\sqrt{ }$ & & & $\sqrt{ }$ & $\sqrt{ }$ & & & S1S2 & & & & & & & & & T.A.J \\
\hline Rio & $\sqrt{ }$ & $\sqrt{ }$ & & $\sqrt{ }$ & & $\sqrt{ }$ & & & S1S2 & & & & & & & & & T.A.J & $\sqrt{ }$ & & & $\sqrt{ }$ & & & & & S2 \\
\hline Risa & $\sqrt{ }$ & $\sqrt{ }$ & & & & & & & S1S2 & & $\sqrt{ }$ & & & & & & & S1 & & $\sqrt{ }$ & & $\sqrt{ }$ & & & & & S1S2 \\
\hline Sefri & $\sqrt{ }$ & $\sqrt{ }$ & & & & $\sqrt{ }$ & & & S1S2 & & & & & & & & & $\mathrm{B}$ & $\sqrt{ }$ & $\sqrt{ }$ & & & & & & & S1S2 \\
\hline Syah & $\sqrt{ }$ & & & & & $\sqrt{ }$ & $\sqrt{ }$ & & S2 & & & & & & & & & B & & 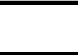 & & & & & & & T.A.J \\
\hline Tobi & $\sqrt{ }$ & & & & & & $\sqrt{ }$ & & S2 & & & $\sqrt{ }$ & & & & $\sqrt{ }$ & & S2 & & & & & & & & & T.A.J \\
\hline Windy & $\sqrt{ }$ & $\sqrt{ }$ & & & & & & & S1S2 & & & & $\sqrt{ }$ & & $\sqrt{ }$ & & & S2 & $\sqrt{ }$ & $\sqrt{ }$ & & & & & & & S1S2 \\
\hline
\end{tabular}


JURNAL GANTANG Pendidikan Matematika FKIP - UMRAH Vol. 1 No. 2, 2016, p-ISSN. 2503-0671, e-ISSN. 2548-5547

\begin{tabular}{|l|l|l|l|l|l|l|l|l|l|}
\hline \multicolumn{7}{|c|}{ Analisis Kesalahan Siswa $/$ Soal Nomor 5 } \\
\hline Nama & W1 & W2 & W3 & W4 & W5 & W6 & W7 & W8 & Ket \\
\hline Abdu & & & & & & & & & T.A.J \\
\hline Alif & & & & & & & & & T.A.J \\
\hline Anggi & & & & & & & & & T.A.J \\
\hline Anjar & & & & & & & & & T.A.J \\
\hline Apriani & & & & & & & & & T.A.J \\
\hline Chand & & & & & & & & & T.A.J \\
\hline Fauzan & & & & & & & & & T.A.J \\
\hline Indah & $\sqrt{ }$ & $\sqrt{ }$ & & & $\sqrt{ }$ & & & & S1S2 \\
\hline Jaya & & & & & & & & & T.A.J \\
\hline Alvon & $\sqrt{ }$ & $\sqrt{ }$ & & & $\sqrt{ }$ & & & & S1S2 \\
\hline Hafiz & & & & & & & & & T.A.J \\
\hline Misla & & & & & & & $\sqrt{ }$ & & S2 \\
\hline Radika & & & & & & & & & T.A.J \\
\hline Ridho & & & & & & & & & T.A.J \\
\hline Rio & & & & & & & & & T.A.J \\
\hline Risa & $\sqrt{ }$ & $\sqrt{ }$ & & & $\sqrt{ }$ & & & & S1S2 \\
\hline Sefri & $\sqrt{ }$ & $\sqrt{ }$ & & & $\sqrt{ }$ & & $\sqrt{ }$ & & S1S2 \\
\hline Syah & $\sqrt{ }$ & $\sqrt{ }$ & & & $\sqrt{ }$ & & & & S1S2 \\
\hline Tobi & & & & & & & & & T.A.J \\
\hline Windy & $\sqrt{ }$ & $\sqrt{ }$ & & & $\sqrt{ }$ & & & & S1S2 \\
\hline
\end{tabular}

Keterangan

$\mathrm{B}=$ Benar

T.A.J $=$ Tidak Ada Jawaban

Kesalahan Sukiman :

S1 = Kesalahan sistematis dan konsisten

S2 = Kesalahan Insidental

Kesalahan Watson :

$\mathrm{W} 1=$ Data tidak tepat (inappropriate data/id)

W2 = Prosedur tidak tepat (inappropriate procedure/ip)

W3 = Data hilang (ommited data/od)

W4 = Kesimpulan hilang (ommited conclusion/oc)

W5 = Konflik level respon (response level conflict/rlc)

W6 = Manipulasi tidak langsung (undirected manipulation/um)

$\mathrm{W} 7=$ Masalah hirarki keterampilan ( skill hierarchy problem/shp)

$\mathrm{W} 8=$ Selain ketujuh kategori diatas (above other/ao) 
$\begin{array}{lll} & \text { Persentase kesalahan yang dilakukan } \\ \text { siswa menurut Sukirman pada kesalahan }\end{array}$ sistematis dan konsisten yaitu sebesar $41,72 \%$ dan pada kesalahan insidental yaitu sebesar $58,28 \%$.

Berdasarkan perhitungan presentase kesalahan siswa menggunakan pendekatan.

$$
\mathrm{P}=\frac{K}{k} \times 100 \%
$$

$\mathrm{K}$ : Jumlah kesalahan di setiap soal

$\mathrm{k}$ : Jumlah seluruh kesalahan

Hasil analisa persentase kesalahan yang dilakukan siswa pada soal nomor 1a yaitu sebesar 7,28\%, persentase kesalahan yang dilakukan siswa pada nomor soal $1 \mathrm{~b}$ yaitu sebesar $9,93 \%$, persentase kesalahan yang dilakukan siswa pada nomor soal 1c yaitu sebesar 7,94\%, persentase kesalahan yang dilakukan siswa pada soal nomor 2 yaitu sebesar $25,82 \%$, persentase kesalahan yang dilakukan siswa pada nomor soal 3 yaitu sebesar $23,17 \%$, kemudian persentase kesalahan yang dilakukan siswa pada nomor soal 4 yaitu sebesar $12,58 \%$, dan persentase kesalahan yang dilakukan siswa pada nomor soal 5 yaitu sebesar $13,24 \%$.

\section{Pembahasan}

Dalam setiap pembelajaran yang berlangsung, proses evaluasi pembelajaran merupakan salah satu hal yang sangat penting dilakukan oleh guru. Suchman (Arikunto dan Jabar, 2010:1) memandang evaluasi sebagai sebuah proses menentukan hasil yang telah dicapai beberapa kegiatan yang direncanakan untuk mendukung tercapainya tujuan.

Salah satu fungsi utama diadakannya evaluasi yaitu sebagai alat ukur keberhasilan untuk mengetahui seberapa jauh tujuan pembelajaran dapat tercapai setelah proses belajar mengajar selesai dilakukan, selain itu fungsi lain diadakannya evaluasi yaitu sebagai alat diagnostik untuk mengetahui letak kelemahan serta kelebihan peserta didik dalam penguasaan konsep matematika yang telah disampaikan.

Dalam penguasaan konsep serta penyelesaian soalan matematika, setiap peserta didik tentu memiliki tingkat pemahaman serta kesalahannya masing-masing. Berdasarkan hasil kajian di atas, kesalahan-kesalahan yang dilakukan oleh siswa telah dikategorikan sesuai dengan kategorisasi kesalahan Watson dan Sukirman. Dengan diketahuinya kelemahan dari siswa sehingga guru dapat mengetahui langkah selanjutnya untuk meminimalisir kesulitan dan kesalahan siswa dalam menyelesaikan serta memahami konsep dan persoalan matematika.

Dari data hasil kajian di atas secara umum kesalahan yang dilakukan siswa pada soal nomor 1 yaitu kesalahan prosedur tidak tepat (inappropriate procedure/ip) pada kategorisasi kesalahan menurut Watson serta kesalahan sistematis dan konsisten pada kategori kesalahan Sukirman. Kesalahan tersebut merupakan kesalahan umum yang terjadi pada soal nomor 1 dari soal a hingga $\mathrm{c}$.

Hal ini disebabkan karena banyak siswa yang kurang memahami sifat-sifat bangun ruang seperti apa dan bagaimana yang dimaksud dengan bidang alas prisma, rusuk, serta bidang tegak dari prisma. Masih banyak siswa yang salah persepsi mengenai bidang alas, siswa beranggapan bahwa bidang alas prisma merupakan bidang bawah dari prisma saja tanpa memahami bahwa bidang tutup juga termasuk dalam bidang alas dari prisma.

Pada soal nomor 2, kesalahan siswa di dominasi oleh kesalahan data tidak tepat (inappropriate data/id) dan kesalahan manipulasi tidak langsung (undirected manipulation/um) pada kategori kesalahan Watson serta kesalahan insidental pada kategori kesalahan Sukirman.

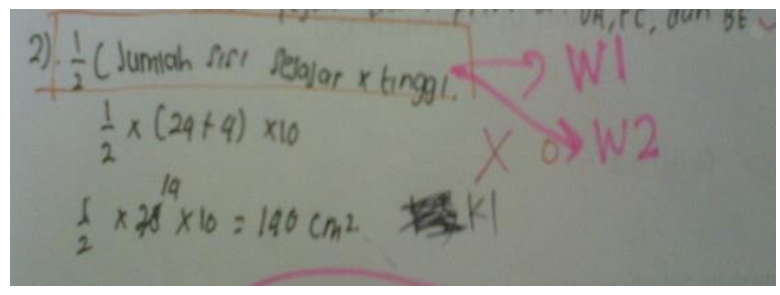

Gambar 1 Kesalahan siswa pada soal nomor 2

Dari penyelesaian diatas dapat dilihat adanya kesalahan siswa yaitu kesalahan dalam mengaplikasikan rumus, karena hal yang diminta dari soalan yaitu luas permukaan prisma namun 
rumus yang digunakan siswa tidak sesuai dengan yang diminta.

Kesalahan lainnya yaitu adanya penyelesaian yang tidak sistematis serta manipulasi tidak langsung dimana sebelum menemukan luas permukaan dari prisma seharusnya siswa dapat menemukan panjang dari sisi alas prisma terlebih dahulu. Namun dalam penyelesaian seperti pada gambar diatas, siswa langsung mengaplikasikan seluruh data yang diketahui pada soalan, ke dalam rumus yang siswa anggap sebagai rumus untuk menghitung luas permukaan prisma.

Selanjutnya pada soal nomor 3, kesalahan siswa di dominansi oleh kesalahan manipulasi tidak langsung (undirected manipulation/um), kesalahan data hilang (ommited data/od), kesalahan masalah hirarki keterampilan (skill hierarchy problem/shp) serta kesalahan prosedur tidak tepat ( inappropriate procedure/ip).

Setiap kesalahan tersebut, tidak memiliki rentang perbedaan persentase kesalahan siswa yang cukup jauh.

Kesalahan Sukirman yang umum terjadi pada soal nomor 3 ini adalah kesalahan insidental. Pada soalan ini, tabel kesalahan siswa terlihat lebih bervariasi di banding soal lainnya.

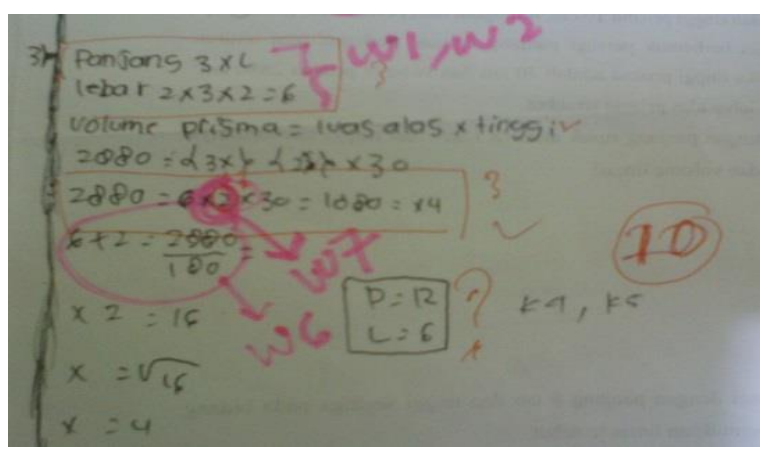

Gambar 2 Kesalahan siswa pada soal nomor 3

Kesalahan pertama yang dapat dilihat dari penyelesaian siswa tersebut yaitu adanya masalah hirarki keterampilan yaitu kesalahan dalam menuliskan operasi matematika, pada gambar yang tertulis tanda W7 dapat dilihat bahwa siswa melakukan kesalahan dalam menuliskan pangkat dari suatu variabel $x$.
Selanjutnya siswa kurang teliti dalam melakukan perhitungan matematis yang dapat dilihat pada gambar yang tertulis tanda W6 dimana pada soalan tersebut siswa dapat diindikasi melakukan manipulasi tidak langsung yaitu siswa dapat memperoleh jawaban dari suatu langkah yang tidak matematis .

Pada soal nomor 4, kesalahan Watson yang umum dilakukan siswa yaitu kesalahan data tidak tepat (inappropriate data/id) dan kesalahan prosedur tidak tepat (inappropriate procedure/ip) serta kesalahan insidental pada kategori kesalahan Sukirman. Hal ini terjadi karena kesalahan siswa dalam mengaplikasikan rumus ke dalam penyelesaian, selain itu kesalahan tersebut juga dapat terjadi karena siswa kurang memahami konsep untuk menghitung volume limas serta kurangnya pemahaman siswa terhadap maksud dari soal yang diberikan.

Pada soal nomor 5, kesalahan Watson yang umum dilakukan oleh siswa yaitu kesalahan data tidak tepat (inappropriate data/id), kesalahan prosedur tidak tepat (inappropriate procedure/ip) serta kesalahan konflik level respon (response level conflict/rlc). Dimana ketiga kesalahan tersebut memiliki persentase yang sama atau seimbang. Sedangkan berdasarkan kategori kesalahan Sukirman, kesalahan dominan yang dilakukan oleh siswa yaitu kesalahan sistematis dan konsisten. Hal ini dapat dilihat dari kesalahan siswa dalam memahami soal.

Pada perintah soal, siswa diminta untuk menghitung luas permukaan suatu limas namun dalam menyelesaikannya siswa menggunakan rumus untuk menghitung volume limas. Dalam hal ini, dapat diindikasikan pula jika siswa kurang memahami konsep dari limas yaitu cara menghitung luas permukaan suatu limas. Dari lima soal yang diberikan, pada soalan inilah banyak siswa yang tidak menjawab soal yang diberikan yaitu sebanyak 13 siswa tidak menjawab soalan ini.

Berdasarkan kategori kesalahan Watson yang telah dijabarkan diatas, secara umum siswa melakukan kesalahan data tidak tepat 
(inappropriate data/id) pada soal nomor 4, kesalahan prosedur tidak tepat (inappropriate procedure/ip) pada soal nomor 1a dan 1c, kesalahan data hilang (ommited data/od) pada soal nomor $1 \mathrm{~b}$, kesalahan kesimpulan hilang (ommited conclusion/oc) pada soal nomor 2 dan 4, kesalahan konflik level respon (response level conflict/rlc) pada soal nomor 3, dan kesalahan manipulasi tidak langsung (undirected manipulation/um) terjadi pada soal nomor 5, serta kesalahan masalah hirarki keterampilan (skill hirarchy problem/shp) dominan terjadi pada soal nomor 3, dan tidak ditemukannya kategori kesalahan Watson selain ketujuh kategori diatas (above other/ao).

Selanjutnya berdasarkan hasil kajian, secara umum kesalahan Watson yang sering dilakukan oleh siswa yaitu kesalahan prosedur tidak tepat (inappropriate procedure/ip). Hal ini ditunjukkan oleh kurangnya pemahaman siswa terhadap konsep untuk menghitung luas permukaan serta volume dari limas dan prisma, hal yang turut menunjang ketidakpahaman siswa ini juga berasal dari kurangnya pemahaman siswa terhadap materi dasar sebelumnya yaitu mengenaai sifat dasar bangun ruang, masih banyaknya siswa yang tidak dapat memahami maksud bidang, rusuk, sisi tegak, garis tinggi dan lain sebagainya mengenai sifat dasar dari bangun ruang. Hal lain yang menunjukkan kesalahan siswa dalam prosedur tidak tepat adalah siswa tidak dapat memahami perintah dan data yang terdapat dari soal dengan baik, sehingga dalam menyelesaikan soalan siswa salah mempersepsi perintah yang dimaksud.

Sedangkan berdasarkan kategori kesalahan Sukirman, kesalahan yang umum dilakukan oleh siswa berdasarkan hasil kajian diatas yaitu kesalahan insidental dimana siswa kurang cermat dalam membaca untuk dapat memahami maksud atau perintah dari soal hal ini sejalan dengan kesalahan menurut Watson yang telah penulis paparkan sebelumnya.

Dari lima soal yang diberikan, siswa paling banyak melakukan kesalahan baik itu kategori kesalahan Watson maupun kategori kesalahan Sukirman pada soal nomor 2, dimana kesalahan paling umum yang dilakukan siswa pada soalan tersebut yaitu kesalahan manipulasi tidak langsung (undirected manipulation/um) atau kesalahan insidental dimana banyak siswa yang melakukan kesalahan dalam penulisan penyelesaian yang kurang teliti serta tidak matematis disertai dengan alasan yang tidak sistematis.

\section{Kesimpulan}

Berdasarkan hasil dan pembahasan dari data yang diperoleh dalam kajian, maka dapat diambil kesimpulan sebagai berikut.

1. Kategori kesalahan Watson yang umum terjadi pada soal nomor 1 yaitu kesalahan prosedur tidak tepat (inappropriate procedure/ip), pada soal nomor 2 dan 3 yaitu kesalahan manipulasi tidak langsung (undirected manipulation/um), pada soal nomor 4 yaitu kesalahan data tidak tepat (inappropriate data/id), dan pada soal nomor 5 kesalahan yang umum dilakukan yaitu kesalahan data tidak tepat (inappropriate data/id), prosedur tidak tepat (inappropriate procedure/ip) dan manipulasi tidak langsung (undirected manipulation/um). Sedangkan kategori kesalahan Sukirman yang umum terjadi pada soal nomor 1 dan 5 yaitu kesalahan sistematis dan konsisten, pada soal nomor 2,3,dan 4 kesalahan yang umum terjadi yaitu kesalahan insidental.

2. Diantara delapan kategorisasi kesalahan Watson, kesalahan yang sering terjadi yaitu kesalahan prosedur tidak tepat (inappropriate procedure/ip) dengan persentase kesalahan sebesar 36,42\% dan kategori kesalahan Sukirman yang umum terjadi yaitu kesalahan insidental dengan persentase kesalahan sebesar $58,28 \%$.

3. Dari lima soal tes yang diberikan, kesalahan terbesar siswa terdapat pada soal nomor 2 dengan persentase kesalahan siswa dalam menyelesaikan soalan tersebut sebesar $25,82 \%$ dibadingkan dengan soal lainnya.

\section{Ucapan Terima Kasih}

Ucapan terimakasih penulis kepada kepala sekolah, guru Matematika, dan siswa kelas VIII 
SMP Muhammadiyah, Tanjungpinang serta kepada Dosen Pendidikan Matematika, Febrian, S.Pd., M.Sc, yang telah membimbing pelaksanaan studi analisis kesalahan dan penulisan artikel imliah ini. Kemudian rekanrekan penaganalisis, mahasiswa Pendidikan Matematika FKIP Universitas Maritim Raja Ali Haji yang turut membantu perencanaan, pelaksanaan, dan penulisan.

\section{Referensi}

Damanik, Ericson. (2014). Pengertian Evaluasi Menurut Ahli. Sumber :

file:///C:/Users/hp/Documents/Pengertia n\%20Evluasi\%20Menurut\%20Ahli\%20 $\% 20$ KUMPULAN\%20ARTIKEL\%20ref erensi\%20.htm.

Faisal, Mirza. (2012). Deskripsi Tingkat Kesulitan Soal (C1, C2, C3, C4, C5, C6). Sumber:file:///C:/Users/hp/Documents/ti ngkat\%20pemahaman\%20pak\%20feb(re ferensi).htm.

Febriana, Tristian.et al. Analisis Kesalahan Siswa Berdasarkan Kategori Kesalahan Watson Dalam Menyelesaikan SoalSoal Himpunan Di Kelas VII D SMP Negeri 11 Jember, 5 halaman. http://repository.unej.ac.d/bitstream/hand le/12346789/64146/TRISTIA\%20FEBRI ANA\%20NILASARI.pdf?sequence $=1$.

Muhibbin Syah, Psikologi Belajar, (Jakarta : PT Rajagrafindo Persada, 2006), h. 68. Sumber:http://digilib.uinsby.ac.id/8721/4 bab2.pdf.

Sudaryono. (2012).halaman 44. Sumber :

http://digilib.uinsby.ac.id/872/5/Bab\%20 2.pdf.

Suherman Erman.(2003). Kamus Matematika, h.

298. Sumber :

http://eprints.uny.ac.id/9509/1

5/BAB\%20II\%20TUTIK-

08301244031.pdf.

Sukirman.(1985). Identifikasi KesalahanKesalahan yang Diperbuat Siswa Kelas III SMP pada setiap Aspek Penguasaan Bahan Pelajaran Matematika. (Malang: tesis tidak dipublikasikan,1985), h.16.
http://digilib.uinsby.ac.id/1998/5/Bab\%2 02.pdf.

Winarsih, Kurnia. et al. (2016). Analisis Kesalahan Siswa Berdasarkan Kategori Kesalahan Menurut Watson Dalam Menyelesaikan Permasalahan Pengolahan Data Siswa Kelas VI SDN Baletbaru 02 Sukowono Jember Tahun Pelajaran 2014/2015, 5 halaman. Sumber:

http://repository.unej.ac.id/bitstream/han dle/123456789/63621/KURNIYA\%20A YU\%20WINARSIH.pdf?sequenc

M. Sulthon Masyhud. (2012). Metode Penelitian Pendidikan Edisi 3, Cetakan ke 1, (Jember: Lembaga Pengembangan Manajemen dan Profesi Kependidikan (LPMPK), 2010) - Hal 80 
JURNAL GANTANG Pendidikan Matematika FKIP - UMRAH

Vol. 1 No. 2, 2016, p-ISSN. 2503-0671, e-ISSN. 2548-5547 